\title{
Assessment and Management of Root Lesion Nematodes in Montana Wheat Production
}

David B. May, Department of Plant Sciences and Plant Pathology, Montana State University, Bozeman 59717; Wendy A. Johnson, Department of Entomology, Kansas State University, Manhattan 66506; Peter C. Zuck, Department of Plant Sciences and Plant Pathology, Montana State University, Bozeman; Chengci C. Chen, Montana State University, Eastern Agricultural Research Center, Sidney 59270; and Alan T. Dyer, Department of Plant Sciences and Plant Pathology, Montana State University, Bozeman

\begin{abstract}
May, D. B., Johnson, W. A., Zuck, P. C., Chen, C. C., and Dyer, A. T. 2016. Assessment and management of root lesion nematodes in Montana wheat production. Plant Dis. 100:2069-2079.

Root lesion nematodes (Pratylenchus spp.) hinder dryland wheat production worldwide. Montana, a leading U.S. wheat production region, has climatic conditions favorable for Pratylenchus spp. A 2006-2007 statewide soil survey revealed damaging populations of Pratylenchus neglectus, primarily in winter wheat production areas of Montana, whereas $P$. thornei was not found. Analyses of wheat yields in infested fields revealed negative correlations between yields and spring nematode populations (all $P<0.05$ and all $R^{2}>0.2$ ). Statewide yield losses due to root lesion nematodes were an estimated 12 and $15 \%$ for winter wheat in 2006 and 2007, respectively. A subsequent study conducted in 2008 to 2009 revealed significant

differences in reproductive success of $P$. neglectus among seven rotation treatments $(P<0.001)$. Nematode populations persisted from spring to fall under fallow, barley, pea, and camelina; increased under winter wheat and canola; and decreased under lentil. Populations were sustained through winter following winter wheat and barley but declined following canola, camelina, pea, lentil, and fallow. A screening of 19 barley lines for resistance to $P$. neglectus revealed significant variation in resistance among entries $(P<0.001)$, with 'Harrington' barley displaying promising levels of resistance. Development of resistant wheat cultivars remains a principal goal in managing this nematode.
\end{abstract}

Root lesion nematodes (Pratylenchus thornei Sher \& Allen and $P$. neglectus (Rensch) Filipjev Schuurmans \& Stekhoven) present a serious challenge to dryland wheat production worldwide (Smiley et al. 2004a; Thompson et al. 2008b). Of the two, P. thornei is reportedly more destructive, causing estimated yield losses of up to $85 \%$ in Australia, $70 \%$ in Israel, $37 \%$ in Mexico, and $50 \%$ in the United States (Armstrong et al. 1993; Nicol and Ortiz-Monasterio 2004; Smiley et al. 2005b). Estimated yield losses due to P. neglectus of up to $30 \%$ have been reported in Australia (Vanstone et al. 2008) and up to $37 \%$ in the Pacific Northwest region of the United States (Smiley et al. 2005c). Whether due to an increased awareness or spread of the nematode, reports of crop damage have been growing over recent years in the United States (Appel et al. 2012; Johnson et al. 2007).

Both $P$. thornei and $P$. neglectus infest wheat roots, resulting in reduced root growth, along with the formation of dark necrotic lesions that can serve as secondary infection sites for root-rotting fungi (Jones et al. 2013). The root damage that results from Pratylenchus infestation hinders a plant's absorption of water and nutrients. Crops infested while growing under moisture stress experience the greatest yield losses (Nicol and Ortiz-Monasterio 2004). Aboveground symptoms are nonspecific and often mistaken for nutrient deficiencies or drought stress (Doyle et al. 1987; Smiley et al. 2005b,c; Thompson et al. 1995; Van Gundy et al. 1974). These include stunted plant growth, chlorosis, and early death of lower leaves, as well as reductions in plant vigor, grain yield, grain quality, and tiller count (Smiley and Nicol 2009).

Root lesion nematodes are endoparasites capable of completing their entire lifecycle within the root systems of host plants (Williams et al. 2002). This ability to multiply within host tissue allows Pratylenchus spp. to thrive in semiarid growing regions where the absence

Corresponding author: A. T. Dyer; E-mail: adyer@montana.edu

Accepted for publication 1 June 2016.

http://dx.doi.org/10.1094/PDIS-02-16-0176-RE

(C) 2016 The American Phytopathological Society of free moisture can limit the activity of free-living nematodes (Vanstone et al. 1998). Like many wheat pathogens, greater population densities of Pratylenchus nematodes build under annual wheat cropping systems as opposed to wheat-fallow rotations (Smiley et al. 2004b). Given that spring population densities of root lesion nematodes negatively correlate with yield for both $P$. neglectus and $P$. thornei, spring survey data for these nematodes have been invaluable in the assessment of their damage (Smiley et al. 2005b,c).

Tools available for the practical management of root lesion nematodes in wheat are limited. For research studies, the nematicide Aldicarb (Temik 15G) has shown efficacy in early protection of root development but, due to its persistence, toxicity, and cost, is not currently labeled for commercial cereal production (Kimpinski et al. 1987). There are reports that tillage can reduce nematode population density in the short term (Lenz and Eisenbeis 2000; López-Fando and Bello 1995) but it has also been shown that tillage can shuffle the trophic relationships among soil fauna such that plant parasites become the dominant nematode group (López-Fando and Bello 1995). This leaves the incorporation of fallow periods or resistant rotational crops (Kratochvil et al. 2004; Taylor et al. 2000) and the use of resistance incorporated into locally adapted wheat cultivars as the primary sources of control for root lesion nematodes.

In areas where wheat is of particular economic importance, alternative resistant rotational crops must be identified and deployed in an attempt to reduce population densities of the nematodes below yieldreducing levels. Use of resistant or nonhost cultivars and crops in rotation have been shown to be as effective as nematicides in controlling Pratylenchus spp. (Taylor et al. 1999). A small number of rotational crops have been identified that are both suitable for lowmoisture environments and economically viable. Reports of root lesion nematode control exist for several rotational crops, including field pea, lentil, canola, and barley (Smiley et al. 2004a, 2005a; Taylor et al. 2000). Unfortunately, the existing literature is conflicted on their efficacy. For crops such as pea and barley, conflicts are perhaps related to the nematode species involved (Gair et al. 1969; Riga et al. 2008; Smiley and Machado 2009; Smiley et al. 2004a; Taylor et al. 2000 ) or to the variability in resistance among cultivars each crop presents (Keil et al. 2009). Other crops such as cruciferous oilseeds (Brassica spp.) are documented hosts of root lesion nematodes 
(Taylor et al. 2000). However, Brassica spp. also produce varying levels of volatile glucosinolates that form 2-phenylethyl isothiocyanate, a compound known to reduce $P$. neglectus population density, upon degradation (Potter et al. 1998; Yu et al. 2005). Assessment of the overall impact of Brassica crops on root lesion nematodes has not been fully explored.

Development of wheat cultivars with resistance, a term describing a plant's ability to inhibit a pathogen's reproductive rate, is the most important and economical tool for long-term management of root lesion nematodes. Resistance to Pratylenchus spp. in wheat has been shown to be largely species specific, meaning that resistance genes that are effective for $P$. thornei are not necessarily effective for $P$. neglectus, and vice versa (Farsi et al. 1995). Problematically, mixed populations of both species are often found in the same field (Smiley et al. 2004a; Thompson et al. 2008a). Therefore, the development of cultivars with dual resistance would greatly simplify selection of an appropriate resistant cultivar for growers experiencing yield loss due to Pratylenchus nematodes. Middle Eastern landrace lines and ancient wheat progenitors have been identified as the most effective sources of root lesion nematode resistance (Hollaway et al. 2000; Nicol et al. 1999, 2001, 2003; Nombela and Romero 1999; Sheedy et al. 2008, 2012; Thompson and Haak 1997; Thompson et al. 1999; Toktay et al. 2006; Zwart et al. 2004, 2005). However, these lines lack the essential adaptation and agronomic traits to be utilized in large-scale production. Resistance genetics from these sources will need to be incorporated into adapted cultivars using backcross breeding regimes; however, the low throughput of phenotypic screenings (Zwart et al. 2005) and a lack of reliable marker data (May 2015) have slowed breeding efforts toward the development of resistant wheat lines such that only a few resistant cultivars are currently available worldwide.

In 2005, P. neglectus was detected in soil samples from a poorly performing wheat field in central Montana. Although root lesion nematodes had been found in Montana before, this was the first association between root lesion nematodes and reduced wheat yield in the state. Subsequently, three projects were carried out: to survey Montana field soils for populations of Pratylenchus, identify resistant rotation crops, and screen resistant barley germplasm.

\section{Materials and Methods}

Soil survey project. Survey methodology. Nematode surveys were conducted in 2006 and 2007 to identify the species of Pratylenchus associated with wheat production in Montana, to define their distribution both spatially and by cropping system, and to assess the damage caused by these nematodes in terms of reduced wheat yield. Seventeen Montana counties were chosen for the survey based on wheat acreage (NASS 2004), with those selected accounting for $82 \%$ of total wheat acreage for the state. All soil samples for the survey were taken after spring planting from April through late June in 2006 and 2007. In 2006, 148 bulked soil samples were collected for processing. Ten fields were sampled in 11 counties, and five to eight fields were sampled in six other counties (Table 1). In all, 117 bulked soil samples were collected for processing in 2007: 11 fields were sampled in one county, 10 fields in seven counties, and two to eight fields in seven other counties (Table 2).

For each field sampled, county agents took nine soil cores in a "W" pattern. The cores were collected starting $30 \mathrm{~m}$ from the edge of the field, with $8 \mathrm{~m}$ separating each core from its neighbor. Cores were taken to a $23-\mathrm{cm}$ depth using a $2.5-\mathrm{by}-30-\mathrm{cm}$ soil core sampler. The nine soil cores were then combined and mixed thoroughly to make a bulked soil sample. The bulked samples were then placed in a soil collection bag labeled with the following information: grower, county, previous crop, and cropping system; either no-till or conventional tillage; and annually cropped or wheat-fallowed.

Soil sample processing. Once soil samples were received, they were placed in cold storage at $4^{\circ} \mathrm{C}$ until processing. The Whitehead tray method was modified to extract nematodes from the soil samples (Whitehead and Hemming 1965). For each soil sample, nematodes were extracted from $200 \mathrm{~g}$ of fresh soil over $48 \mathrm{~h}$ at $20^{\circ} \mathrm{C}$ using 1 liter of tap water, after which the extraction water was passed through a $20-\mu \mathrm{m}$ mesh sieve. The nematodes were stored in water at $4^{\circ} \mathrm{C}$ until microscopic examination could be conducted. Extracted nematode populations were examined for the presence of both Pratylenchus spp. known to infect wheat (P. neglectus and P. thornei) and stunt nematodes (Tylenchorhynchus spp.). Concurrent with nematode extractions, percent soil moisture was determined by drying $100 \mathrm{~g}$ of fresh soil at $70^{\circ} \mathrm{C}$ for $48 \mathrm{~h}$. Time from receiving to processing samples varied from 1 day to 2 weeks.

Nematode extraction and quantification. The nematode suspension ( $2 \mathrm{ml}$ ) was placed into a McMaster Counting Slide (Chalex Corporation, Wallowa, OR) and the nematodes were counted using 10× magnification on a Nikon Eclipse 50i microscope (Kent, WA). Resulting counts from the $200-\mathrm{g}$ soil samples were converted to nematodes per kilogram of dry soil. Nematode identifications were conducted based on length, width, and vulva position in relation to percent body length. $P$. neglectus is distinguishable from $P$. thornei

Table 1. Mean population density and incidence of root lesion (Pratylenchus neglectus) and stunt (Tylenchorhynchus spp.) nematodes for 17 counties sampled in Montana in 2006

\begin{tabular}{|c|c|c|c|c|c|c|}
\hline County & $N^{\mathbf{a}}$ & Root lesion (nematodes/kg of soil) ${ }^{\mathbf{b}}$ & Root lesion $(\%)^{\mathrm{c}}$ & Stunt (nematodes/kg of soil) ${ }^{b}$ & Stunt $(\%)^{\mathrm{c}}$ & Wheat area (ha) ${ }^{d}$ \\
\hline Chouteau & 10 & 3,844 & 60 & 1,036 & 90 & 215,700 \\
\hline Fergus & 10 & 3,375 & 100 & 2,310 & 100 & 76,700 \\
\hline Cascade & 10 & 3,252 & 80 & 667 & 90 & 57,700 \\
\hline McCone & 10 & 1,440 & 70 & 2,485 & 100 & 95,500 \\
\hline Hill & 10 & 880 & 60 & 3,005 & 100 & 181,000 \\
\hline Pondera & 10 & 679 & 40 & 1,410 & 100 & 72,400 \\
\hline Toole & 10 & 565 & 40 & 1,860 & 100 & 96,100 \\
\hline Yellowstone & 6 & 301 & 83 & 2,311 & 100 & 40,900 \\
\hline Glacier & 10 & 89 & 20 & 2,544 & 90 & 54,000 \\
\hline Phillips & 6 & 73 & 50 & 420 & 83 & 52,500 \\
\hline Roosevelt & 8 & 61 & 13 & 1,672 & 100 & 138,500 \\
\hline Valley & 10 & 5 & 10 & 1,460 & 90 & 117,900 \\
\hline Liberty & 10 & 0 & 0 & 2,970 & 100 & 100,700 \\
\hline Dawson & 5 & 0 & 0 & 1,900 & 100 & 66,500 \\
\hline Sheridan & 7 & 0 & 0 & 202 & 28 & 132,400 \\
\hline Richland & 6 & 0 & 0 & 303 & 100 & 61,800 \\
\hline Daniels & 10 & 0 & 0 & 1,895 & 100 & 90,800 \\
\hline
\end{tabular}

a Number of fields sampled.

b Mean root lesion or stunt nematode population density indicates the mean of all samples taken from a county in 2006 . All soil samples taken after spring planting, April to June 2006. Nematodes were extracted from a 200-g subsample from each bulked field soil sample using the 48-h tray method described by Whitehead and Hemming (1965). Nematodes were enumerated on the microscope and resulting counts were converted to nematodes per kilogram of dry soil.

c Root lesion (P. neglectus) or stunt (Tylenchorhynchus spp.) incidence as a percentage of field samples examined from each county.

${ }^{d}$ Based on 2002-2003 county estimates (NASS 2004). 
by being notably shorter and wider and having a more pointed tail than the dorsally flattened tail of $P$. thornei; diagnostic vulva position for $P$. neglectus is between 80 and $87 \%$ of the body length versus 73 to $80 \%$ of body length for P. thornei (Handoo and Golden 1989). Tylenchorhynchus spp. were identified to genus level by having a strong stylet, nonoverlapping esophagus, didelphic vulva position, and conical tail shape (Mai and Mullin 1960). In total, 12 representative samples were sent to the Oregon State University nematode diagnostic laboratory and 10 samples sent to Columbia Basin Agricultural Research Station (Pendleton, OR) for confirmation of results.

In addition to the above statewide soil survey, two field sites were selected in 2006 and 2007. The 2006 field site was a winter wheat field ('Genou') infested with $P$. neglectus in Ulm, MT, while the 2007 site was an infested spring wheat field ('Vida') at the Arthur H. Post Farm in Bozeman, MT. Both studies utilized randomly selected 3-m segments of row to analyze the relationship between spring population densities of $P$. neglectus and subsequent fall grain yield. In spring 2006 and 2007, three soil cores were removed from the center $1 \mathrm{~m}$ of each selected row, bulked, and subjected to the nematode extraction and quantification protocols described above. Selected rows were flagged and the global positioning (GPS) coordinates were recorded for each. In fall 2006 and 2007, grain was harvested and weighed from $1 \mathrm{~m}$ of row on either side of the sampled center portion. The resultant grain yield in grams was converted to kilograms per hectare. Overall, 20 and 24 randomly selected 3-m segments were collected in 2006 and 2007, respectively.

Crop rotation project. Experimental design. A field crop rotation experiment was conducted in 2008 and 2009 at the Central Agricultural Research Center (CARC) in Moccasin, MT. This site was previously identified as having substantial populations of $P$. neglectus. Precipitation totaled 32 and $28 \mathrm{~cm}$ for the 2008 and 2009 crop years, respectively, with $23 \mathrm{~cm}$ falling between April and August 2008 and $17 \mathrm{~cm}$ falling during the same period in 2009. Average long-term precipitation for this site is $39 \mathrm{~cm}$ for crop years (September to August), with $29 \mathrm{~cm}$ falling between April and September (CARC 2016). Mean high temperatures for July and August were 29 and $26^{\circ} \mathrm{C}$ for 2008 and 2009, respectively. Soil at CARC is a shallow clay loam with a plant-limiting hardpan layer at around $60 \mathrm{~cm}$ in depth.

The crop rotations included fallow-winter wheat, barley-winter wheat, canola-winter wheat, camelina-winter wheat, pea-winter wheat, and lentil-winter wheat. The dryland crop rotation study was fully phased, and the rotation treatments were replicated four times. All rotation treatments-fallow, winter wheat ('Yellowstone'), barley ('Haxby'), canola ('Hyola 357 Magnum'), camelina ('Blaine Creek'), lentil ('Red Chief'), and pea ('Delta') — appeared each year in 2008 and
2009. Plots measured 8 by $20 \mathrm{~m}$, and all crops in the rotation study were planted on $30-\mathrm{cm}$ row spacing. All plots were managed with no-till practices. Crops were managed following the local production guides (McVay and Lamb 2008; McVay et al. 2009, 2010, 2013).

Field soil sampling for root lesion nematodes. Nematodes were extracted from soil samples taken with manually operated probes $(2.5 \mathrm{~cm}$ in diameter) to a depth of $30 \mathrm{~cm}$. GPS coordinates were used to record the location where each soil core was taken. This enabled a more accurate resampling of locations for each sampling date, thereby reducing the variability associated with the horizontal distribution of soilborne nematodes (Taylor and Evans 1998). Spring sampling was conducted shortly after emergence to ensure that the nematodes were active. Within these spring and fall periods, samples were taken from the field when soil moisture content was optimum for probing, or approximately $15 \%$ water content. Samples for the rotation experiment were taken on 15 May and 23 October 2008 and 27 May and 3 September 2009. Samples from the barley trials were taken on 15 May and 23 October 2008 and 21 May and 19 September 2009.

Six soil cores were taken $150 \mathrm{~cm}$ apart from each plot for the rotation experiment as well as the barley cultivar trials. These six cores were then combined and mixed in a plastic bag for a single bulked sample. The bulked samples were stored at $4^{\circ} \mathrm{C}$ while awaiting processing. Storage times never exceeded 4 weeks (Hollaway et al. 2003). Nematode extraction, identification, and quantification methodology for the 2008-2009 survey was identical to that utilized in the 2006-2007 statewide survey.

Barley greenhouse and field studies. Barley greenhouse cultivar trials. The Arthur H. Post Agronomy Farm located in Bozeman, MT was previously identified as having high populations of $P$. neglectus. To establish working populations of the pathogen, field soil was collected at the Post Farm and mixed with equal parts coarse sand, placed in 20-cm pots, and planted with six seeds of susceptible 'Machete' wheat (Taylor et al. 2000). The resulting pot cultures were maintained for 8 to 12 weeks at diurnal temperatures of $22^{\circ} \mathrm{C}$ by day and $18^{\circ} \mathrm{C}$ by night. Day length was supplemented to $14 \mathrm{~h}$ with $430-\mathrm{W}$ sodium halide lamps during winter months. Root lesion nematodes were extracted from the pot culture soil using the modified Whitehead tray method, as described for the 2006-2007 survey. Nematode population counts were then determined for the extracted suspension. Immediately after extraction, these nematodes were used as inoculum for all greenhouse experiments.

Barley was planted in a steam-pasteurized mixture of 50\% loamy field soil and 50\% coarse sand. Each $15-\mathrm{cm}$ pot was first lined with a nonporous plastic bag to prevent nematode leaching. The pots were

Table 2. Mean population density and incidence of root lesion (Pratylenchus neglectus) and stunt (Tylenchorhynchus spp.) nematodes for 14 counties sampled in Montana, 2007

\begin{tabular}{|c|c|c|c|c|c|c|}
\hline County & $N^{\mathrm{a}}$ & Root lesion (nematodes/kg of soil) ${ }^{b}$ & Root lesion $(\%)^{\mathrm{c}}$ & Stunt (nematodes/kg of soil) ${ }^{b}$ & Stunt $(\%)^{\mathrm{c}}$ & Wheat area $(\text { ha })^{d}$ \\
\hline Chouteau & 10 & 3,306 & 80 & 5,895 & 90 & 215,700 \\
\hline Fergus & 10 & 2,400 & 90 & 756 & 90 & 76,700 \\
\hline Cascade & 6 & 2,670 & 100 & 1,220 & 50 & 57,700 \\
\hline McCone & 10 & 1,285 & 50 & 3,437 & 100 & 95,500 \\
\hline Hill & 10 & 953 & 50 & 1,330 & 100 & 181,000 \\
\hline Pondera & 11 & 811 & 45 & 725 & 45 & 72,400 \\
\hline Toole & 10 & 2,375 & 20 & 1,001 & 80 & 96,100 \\
\hline Glacier & 10 & 100 & 30 & 1,825 & 90 & 54,000 \\
\hline Phillips & 6 & 0 & 0 & 538 & 83 & 52,500 \\
\hline Roosevelt & 8 & 24 & 13 & 1,306 & 88 & 138,500 \\
\hline Valley & 2 & 29 & 50 & 1,337 & 100 & 117,900 \\
\hline Liberty & 10 & 385 & 20 & 4,254 & 100 & 100,700 \\
\hline Sheridan & 7 & 0 & 0 & 751 & 86 & 132,400 \\
\hline Daniels & 5 & 0 & 0 & 1,020 & 60 & 90,800 \\
\hline
\end{tabular}

a Number of fields sampled.

${ }^{\mathrm{b}}$ Mean root lesion or stunt nematode population density indicates the mean of all samples taken from a county in 2007. All soil samples taken after spring planting, April to June 2007. Nematodes were extracted from a 200-g subsample from each bulked field soil sample using the 48-h tray method described by Whitehead and Hemming (1965). Nematodes were enumerated on the microscope and resulting counts were converted to nematodes per kilogram of dry soil.

${ }^{\mathrm{c}}$ Root lesion (P. neglectus) or stunt (Tylenchorhynchus spp.) incidence as a percentage of field samples examined from each county.

${ }^{\mathrm{d}}$ Based on 2002-2003 county estimates (NASS 2004). 
filled with $800 \mathrm{~g}$ of the soil mixture. Five seeds were then placed on top of the soil. The nematode suspension was pipetted onto the surface of the soil in the area of the seed. Each experimental pot was inoculated with 1,000 P. neglectus adults. The same soil mix (200 g) was then added to the pots to cover the seed and nematodes. Osmocote 14-14-14 slow-release fertilizer pellets (3 g; Scotts Company, LLC, Marysville, $\mathrm{OH}$ ) were sprinkled on top of the soil. The pots were then watered to maintain field capacity. Fourteen days after emergence, the pots were thinned to one plant per pot.

For each variety trial, 19 barley varieties were planted in a randomized complete block design consisting of four blocks. Each block included known resistant ('Excalibur') and susceptible ('Machete') wheat cultivars as controls (Taylor et al. 2000). The experimental area was surrounded with barley plants ('Haxby') to reduce edge effects. The plants were grown for a period of 12 weeks under conditions described above for the pot cultures, then processed for counting $P$. neglectus populations.

To count final $P$. neglectus populations, all greenhouse barley plants were cut $2 \mathrm{~cm}$ above the soil surface after 12 weeks of growth. Soil bags were removed from the pots, sealed, and stored at $4^{\circ} \mathrm{C}$. The nematodes were then extracted from the soil samples within 4 weeks of harvest to minimize losses of nematodes during storage (Hollaway et al. 2003). Soil samples were processed using the Whitehead tray method and nematodes were identified and quantified as described above for the 2006-2007 survey. A concurrent 100-g subsample was also removed to determine percent soil mass.

Barley field cultivar trials. The dryland barley trials consisted of 20 cultivars replicated three times each in a randomized block design. Nine of these cultivars were present in both 2008 and 2009. Plots measured 2 by $4 \mathrm{~m}$ with $30-\mathrm{cm}$ row spacing. Seed was planted at a rate of $57 \mathrm{~kg} / \mathrm{ha}$ with a double disk seeder. A 10-10-10-5 NPKS fertilizer was applied with the seed and the plots were later top dressed with urea $\mathrm{N}$ at $49 \mathrm{~kg} / \mathrm{ha}$. The 2008 barley nursery was planted into winter wheat stubble, and the 2009 nursery was planted into untilled camelina stubble. Plots in both years were managed with no-till and treated as needed with Bronate herbicide (2-methyl-4-chlorophenoxyacetic

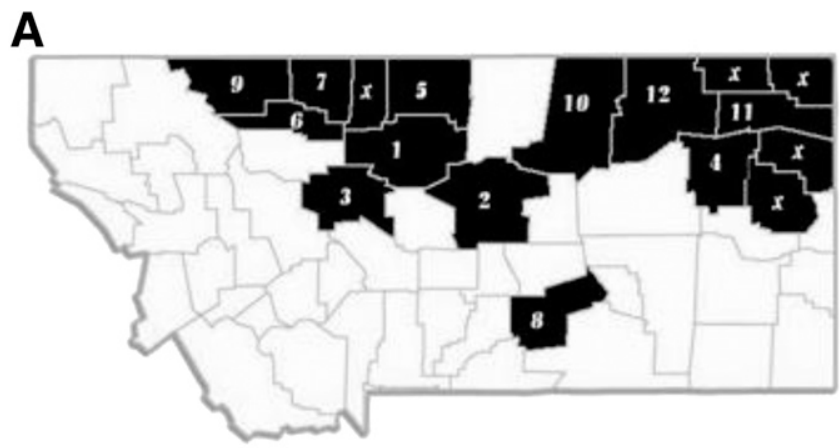

B

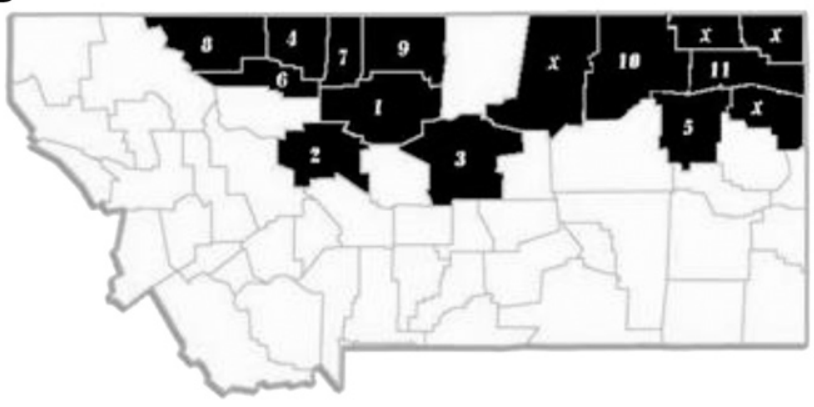

Fig. 1. Montana counties surveyed for root lesion nematode (Pratylenchus spp.) in A, 2006 and B, 2007. Counties are ranked based on average Pratylenchus neglectus spring population densities ( $P$. thornei was not found in the survey). Number 1 indicates the county with greatest mean $P$. neglectus population density and number 12 the smallest; $x$ represents counties sampled where no Pratylenchus sp. was found. acid + bromoxynil) at 2.3 liters/ha. Barley was seeded on 18 April 2008 and 10 April 2009, and harvested on 25 June 2008 and 6 July 2009. Soil samples were taken and nematodes were extracted following the same procedure described in the dryland crop rotation study.

Statistical analysis. The survey study utilized a $t$ test analysis to perform statistical comparisons of mean Pratylenchus population densities based on information reported along with sample material, including the previous year's crop (spring or winter wheat), wheatfallow versus annual cropping systems, and conventional versus no-till field management. Simple linear regression was used to test for correlation of mean root lesion nematode population densities for counties between the 2006 and 2007 survey years. To test for a relationship between spring soil $P$. neglectus population density and grain yield from the 2006 and 2007 field studies, a simple linear regression model was fit using spring $P$. neglectus population density as the explanatory variable and grain yield as the response variable.

Analysis of variance (ANOVA) was performed on all rotation study data, with the log-transformed reproductive factor $\log (\mathrm{Rf})$ as the response variable. Reproductive factors $(\mathrm{Rf})$ for the rotation study and barley cultivar trials were calculated as $\mathrm{Pf} / \mathrm{Pi}$, where $\mathrm{Pf}=$ final $P$. neglectus population density as measured in fall and $\mathrm{Pi}=$ initial population density as measured in spring. Additionally, overwinter reproductive factors (ORf) for the rotation study were calculated as a ratio of postemergence $P$. neglectus population densities in 2009 over the postharvest $P$. neglectus population densities measured in 2008. If the $P$ value obtained from the overall ANOVA provided evidence $(P<0.05)$ of at least one difference in mean Rf among the treatments, a protected Fisher's least significant difference (LSD) test was used to distinguish treatment means. For the rotation experiments, the treatments were the different crop species in the individual years. Aside from being analyzed for individual year effects, the 2-year rotations were analyzed using area under the population curve (AUPC) as the response variable, with the four population measurements making up the curve. For the barley field trials, cultivar means were separated and assigned ranks to the varieties with respect to $P$. neglectus Rf. All Rf were log-transformed in order to stabilize variances. For all experiments, a block factor was included to account for variance resulting from differences in environmental conditions across the experimental area. The general linear model used was $\log \mathrm{Rf}=$ block + year + cultivar. For experiments that were repeated, an $F$-max test was used to assess homogeneity of variance between like experiments (Kuehl 2000). Experiments that were determined to have homogeneous variances were combined and analyzed as a single data set. All statistical procedures were conducted using SAS statistical software (v. 9.3; SAS Institute Inc., Cary, NC).

\section{Results}

Soil survey project. Root lesion nematodes (Pratylenchus spp.). In 2006, P. neglectus was identified in 57 of the 148 samples examined, comprising 12 of the 17 counties surveyed (Fig. 1A). Populations of $P$. neglectus were prominent in north-central Montana. Field samples taken from Chouteau, Fergus, and Cascade Counties had mean spring population densities of $P$. neglectus at $3,844,3,375$, and 3,252 nematodes/kg of soil, respectively (Table 1). Pratylenchus spp. were not found in fields of the northeastern-most portion of the state, including Daniels, Sheridan, Richland, and Dawson Counties.

Specimens of $P$. neglectus were identified in 47 of the 117 samples examined in 2007, involving 11 of the 15 counties surveyed in that year. Due to issues with sample quality, data for Richland County was omitted from further statistical analysis in 2007. The greatest population densities of $P$. neglectus were predominantly in the north-central counties of Chouteau $(\bar{x}=3,306$ nematodes $/ \mathrm{kg}$ of soil), Cascade $(\bar{x}=2,670$ nematodes $/ \mathrm{kg}$ of soil), and Fergus $(\bar{x}=2,400$ nematodes $/ \mathrm{kg}$ of soil, Table 2). Pratylenchus spp. were not found in Phillips County during 2007, although the nematode was detected in soil samples from that county in the previous year. Samples from the far northeast corner of Montana once again contained no Pratylenchus spp. (Fig. 1B).

Statistical comparisons of samples containing P. neglectus in 2006 provided strong evidence of a difference in mean spring nematode 
population density between fields previously planted to winter wheat and fields previously planted to spring wheat ( $P=0.02$; Fig. $2 \mathrm{~A})$. The mean 2006 P. neglectus population density for fields planted to winter wheat in the prior growing season was 3,390 nematodes $/ \mathrm{kg}$ of dry soil, compared with 1,275 nematodes/kg of dry soil for fields previously planted with spring wheat. The results of statistical tests indicated no significant difference $(P=0.14)$ in mean spring nematode population density between fields managed with conventional tillage $(\bar{x}=1,672$ nematodes $/ \mathrm{kg}$ of soil $)$ and fields managed as no-till $(\bar{x}=$ 2,886 nematodes $/ \mathrm{kg}$ of soil). The difference in mean 2006 spring $P$. neglectus population density between annually cropped and wheatfallowed fields was also not significant $(P=0.51)$. The mean spring 2006 root lesion nematode population density was 2,800 nematodes $/ \mathrm{kg}$ of soil for annually cropped fields and 2,134 nematodes $/ \mathrm{kg}$ of soil for wheat-fallowed fields.

In 2007, analysis of soil samples infested with $P$. neglectus revealed that fields planted previously to winter wheat had larger mean spring nematode population densities $(\bar{x}=4,045$ nematodes $/ \mathrm{kg}$ of soil) than fields previously planted to spring wheat $(\bar{x}=1,921$ nematodes/kg of soil); however, the difference between these means was not significant $(P=0.15$; Fig. 2B). As in 2006, further comparisons of 2007 mean field Pratylenchus population densities in terms of management yielded no evidence of a difference between no-till and conventional till production fields $(P=0.42)$ and between annually

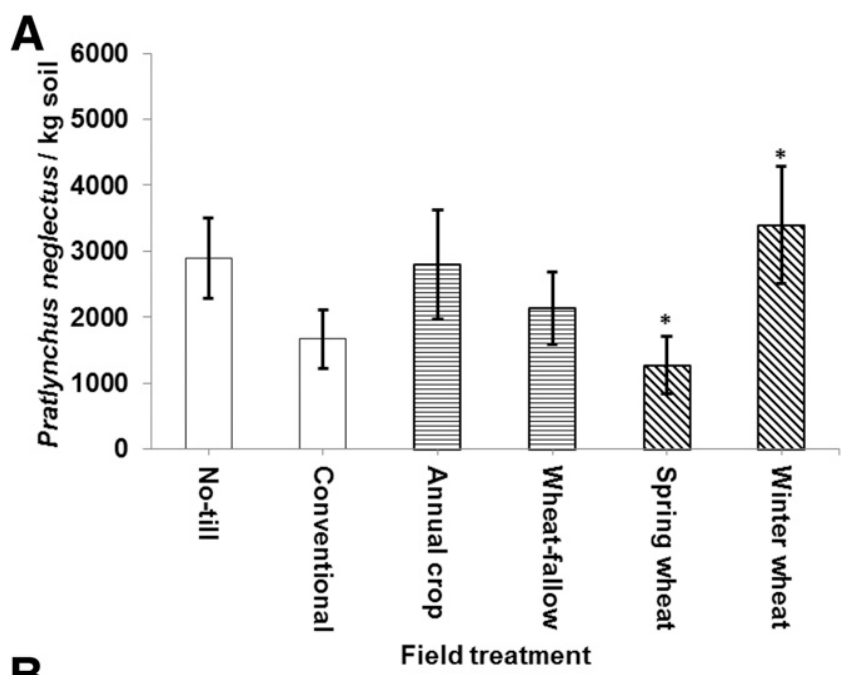

B

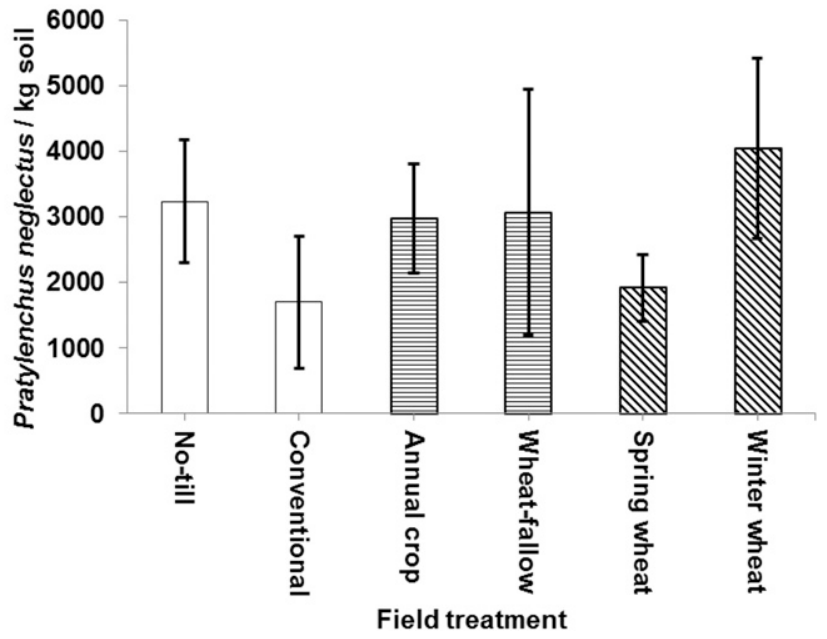

Fig. 2. Comparison of root lesion nematode (Pratylenchus neglectus) spring population densities in no-till versus conventional, annual crop versus wheatfallow, and spring wheat versus winter wheat in A, 2006 and B, 2007. Hash marks represent standard error and an asterisk $\left(^{*}\right)$ indicates a significant difference between treatments $(P=0.02)$. cropped and wheat-fallowed fields $(P=0.95)$. The mean spring 2007 nematode population density for fields managed as no-till was 3,235 nematodes/kg of dry soil, as opposed to 1,699 nematodes $/ \mathrm{kg}$ of dry soil for fields managed with conventional tillage. Annually cropped fields exhibited a mean spring 2007 population density of 2,974 nematodes $/ \mathrm{kg}$ of dry soil compared with the 2007 mean of 3,072 nematodes $/ \mathrm{kg}$ of dry soil for fields that were wheat fallowed.

Among the 17 counties surveyed in 2006, 15 were resampled in the 2007 survey. Simple linear regression analysis for 14 of the 15 resampled counties (Richland County samples were omitted) indicated a strong correlation between the first and second year's mean root lesion nematode population $\left(R^{2}=0.81, P<0.01\right)$. $P$. thornei was not detected in any of the samples examined. An additional, unknown species of Pratylenchus was detected; however, this species was encountered too infrequently in samples to conduct any meaningful statistical comparison.

Stunt nematodes (Tylenchorhynchus spp.). Stunt nematodes were recovered from $92 \%$ of all samples examined and in all counties surveyed in 2006. The mean spring 2006 Tylenchorhynchus population density for fields harboring stunt nematodes was found to be 1,674 nematodes $/ \mathrm{kg}$ of dry soil. The mean spring 2006 stunt nematode population density was significantly greater in annually cropped fields ( $\bar{x}=2,082$ nematodes $/ \mathrm{kg}$ of soil) than wheat-fallowed fields $(\bar{x}=1,357$ nematodes/kg of dry soil $)(P=0.01$; Fig. 3A). Although

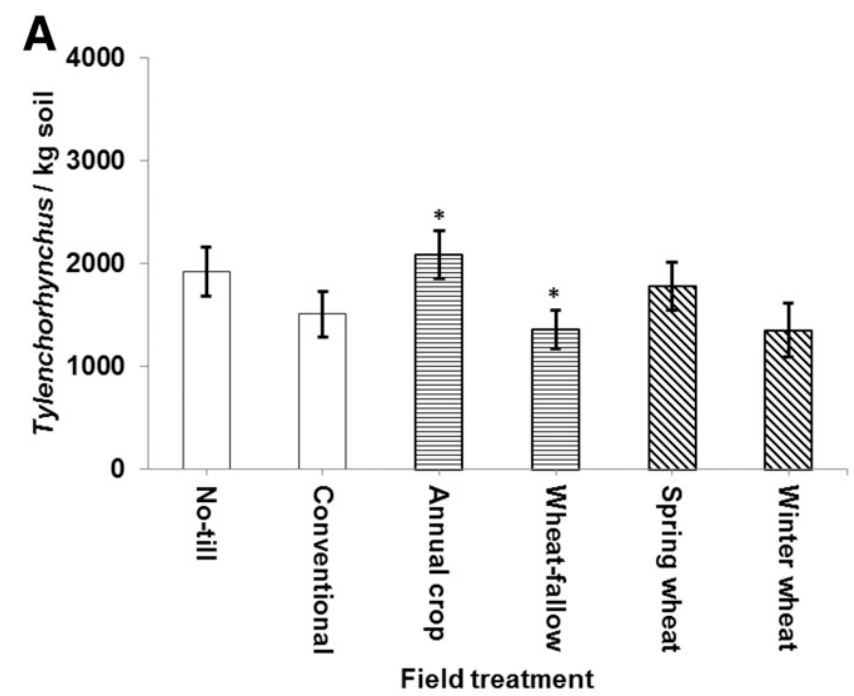

B

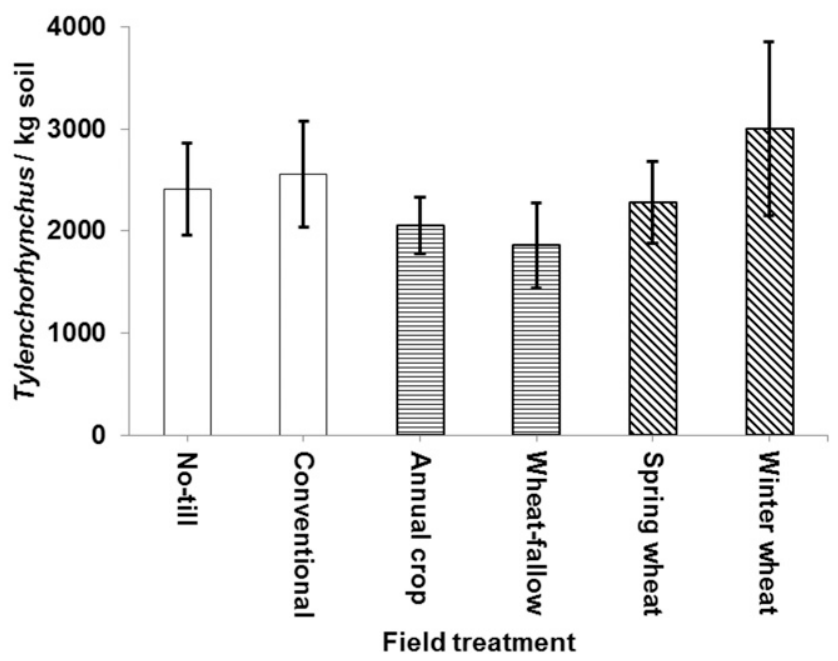

Fig. 3. Comparison of stunt nematode (Tylenchorhynchus spp.) spring population densities in no-till versus conventional, annual crop versus wheat-fallow, and spring wheat versus winter wheat in A, 2006 and B, 2007. Hash marks represent standard error and an asterisk $\left(^{*}\right)$ indicates a significant difference between treatments $(P=0.01)$. 
the difference in mean Tylenchorhynchus population density between the tillage system (no-till or conventional) and growth habit (spring or winter) treatments was not significant (both $P>0.05$ ), the mean spring 2006 stunt nematode population density was greater for no-till fields $(\bar{x}=1,920$ nematodes/kg of dry soil) when compared with conventionally tilled fields $(\bar{x}=1,504$ nematodes $/ \mathrm{kg}$ of dry soil); a greater mean 2006 stunt nematode population density was observed in fields with previous spring wheat crops $(\bar{x}=1,778$ nematodes $/ \mathrm{kg}$ of dry soil) compared with fields with previous winter wheat crops $(\bar{x}=1,348$ nematodes $/ \mathrm{kg}$ of dry soil).

For 2007, stunt nematode populations were present in $83 \%$ of all samples examined and in all counties involved. Fields containing Tylenchorhynchus spp. had a mean spring 2007 population density

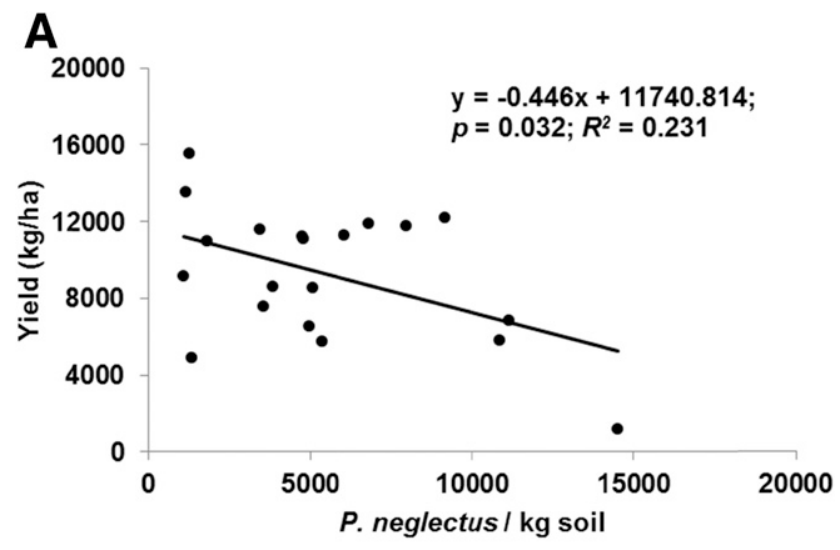

B

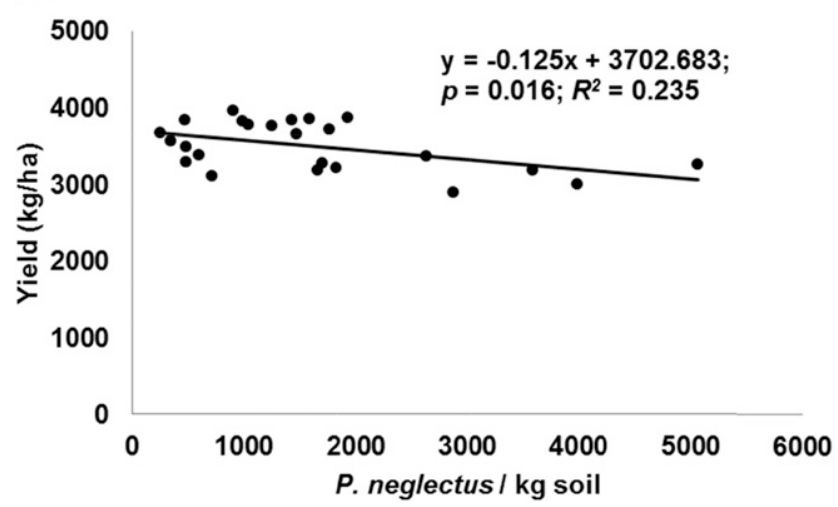

Fig. 4. Simple linear regression analyses between spring field plot Pratylenchus neglectus populations and corresponding fall field plot yields for $\mathrm{A}$, winter wheat (Genou) in Ulm, MT in 2006 and B, spring wheat (Vida) in Bozeman, MT in 2007. of 2,358 nematodes/kg of dry soil. No significant differences in mean spring 2007 stunt nematode population densities were observed, based on statistical comparisons between cropping system (annual or wheatfallow), tillage system (no-till or conventional), or growth habit (spring or winter) treatments (all $P>0.05$; Fig. 3B). Mean 2007 population densities were similar in annually cropped fields and in fallow fields ( $\bar{x}=2,054$ and 1,858 nematodes/kg of dry soil, respectively), no-till systems and conventional systems $(\bar{x}=2,409$ and 2,551 nematodes $/ \mathrm{kg}$ of dry soil, respectively), as well as spring wheat and winter wheat fields $(\bar{x}=2,276$ and 3,002 nematodes/kg of dry soil, respectively).

Regression analysis of wheat yield versus $\mathrm{P}$. neglectus population. A linear relationship between grain yield and spring $P$. neglectus population density is evident from the scatter plots of the 2006 winter wheat and 2007 spring wheat fields (Fig. 4). In both years, the analysis provided evidence that an increase in initial $P$. neglectus population density was associated with a lower grain yield (2006 winter wheat trial: $P=0.032, R^{2}=0.231 ; 2007$ spring wheat trial: $P=$ $\left.0.016 ; R^{2}=0.235\right)$. An increase in mean spring $P$. neglectus population density by 2,000 nematodes $/ \mathrm{kg}$ of soil was associated with an estimated $7.6 \%$ loss in grain yield for winter wheat, while the same increase in initial pathogen density was associated with an estimated $6.8 \%$ loss in grain yield for spring wheat. Using the estimated mean spring statewide $P$. neglectus population densities for winter and spring wheat fields from the 2006 and 2007 surveys, along with the linear models we obtained, estimated statewide yield reductions due to root lesion nematodes in 2006 would have been 12.9 and $4.3 \%$ for winter and spring wheat, respectively. The estimated statewide loss in yield would have been 15.4 and $6.5 \%$ for winter and spring wheat fields in 2007.

Crop rotation project. The mean initial nematode population density for the 2008 rotation study was 625 nematodes $/ \mathrm{kg}$ of soil. At the 23 October postharvest sampling date, these populations had increased to an average of 1,688 nematodes $/ \mathrm{kg}$ of soil. Based on ANOVA, significant differences in mean final Rf occurred among the crops evaluated in the 2008 experiment $(P<0.001$; Table 3$)$. In particular, winter wheat was the best host for $P$. neglectus, with a mean Rf of 8.6. A Fisher's LSD test indicated that the mean Rf of winter wheat was significantly different from that of any other entry $(P<0.001)$. Canola was the second-best host for $P$. neglectus in the 2008 study, with mean $\mathrm{Rf}$ of 3.8. Of the remaining treatments, Fisher's LSD test showed no evidence that any were significantly different from neutral $(\mathrm{Rf}=1)$ in terms of their mean nematode reproductive rates, although there were significant differences in mean $\mathrm{Rf}$ among them $(\alpha=0.05)$. In particular, the P. neglectus population density in fallow plots increased by a mean factor of 2.8; weeds and volunteer crop growth were controlled during the fallow treatments in the trial. P. neglectus populations had a negligible change under camelina. Nematode populations declined, on average, in plots of pea, lentil, and barley, although evidence from the post hoc

Table 3. Pratylenchus neglectus reproductive factors (Rf) for rotation crops in 2008 and $2009^{a}$

\begin{tabular}{|c|c|c|c|c|c|c|c|c|c|}
\hline \multirow[b]{2}{*}{ Crop } & \multirow[b]{2}{*}{$n$} & \multicolumn{4}{|c|}{ Mean 2008} & \multicolumn{4}{|c|}{ Mean 2009} \\
\hline & & $\mathbf{P i}^{\mathbf{b}}$ & $\mathbf{P f}^{\mathrm{c}}$ & Rf & $\overline{\log (\mathbf{R f})^{d}}$ & $\mathbf{P i}^{\mathbf{e}}$ & Pf $^{f}$ & Rf & $\overline{\log (\operatorname{Rf})^{d}}$ \\
\hline Winter wheat & 24 & 328 & 2376 & 8.6 & 0.835 & 173 & 1121 & 11.8 & 0.787 \\
\hline Canola & 4 & 942 & 2393 & 3.8 & 0.444 & 6178 & 11290 & 4.9 & 0.416 \\
\hline Pea & 4 & 1094 & 567 & 0.7 & -0.244 & 3839 & 5136 & 1.4 & 0.134 \\
\hline Barley & 4 & 1051 & 474 & 0.6 & -0.343 & 2159 & 2229 & 1.0 & 0.001 \\
\hline Camelina & 4 & 833 & 594 & 1.0 & -0.041 & 3868 & 2611 & 1.1 & -0.072 \\
\hline Fallow & 4 & 839 & 1447 & 2.8 & 0.211 & 3252 & 1254 & 0.4 & -0.438 \\
\hline Lentil & 4 & 768 & 522 & 0.8 & -0.110 & 2303 & 330 & 0.3 & -0.777 \\
\hline $\mathrm{LSD}_{0.05^{\mathrm{g}}}$ & $\cdots$ & $\cdots$ & $\ldots$ & $\ldots$ & 0.344 & $\ldots$ & $\ldots$ & $\cdots$ & 0.459 \\
\hline
\end{tabular}

a $\mathrm{Rf}=\mathrm{Pf} / \mathrm{Pi}$, where $\mathrm{Pf}=$ final $P$. neglectus and $\mathrm{Pi}=$ initial P. neglectus population density in nematodes per kilogram of soil.

b Samples taken 15 May 2008.

c Samples taken 23 October 2008.

d Significant differences $(F$ test, $P<0.0001)$ in mean Rf among crops.

e Samples taken 27 May 2009.

f Samples taken 3 September 2009.

$\mathrm{g}$ Least significant difference (LSD, $\alpha=0.05$ ) values for mean $\log (\mathrm{Rf})$. 
tests indicated that these crops had a mean Rf that was significantly different from neither camelina nor an overall neutral effect $(\mathrm{Rf}=1)$ on $P$. neglectus populations.

In 2009, spring nematode population densities in plots following winter wheat averaged 3,600 nematodes/kg of soil. Conversely, initial population densities under the 2009 winter wheat plots, which followed the 2008 alternative crops, averaged 173 nematodes $/ \mathrm{kg}$ of soil. For the rotational study in 2009, there were significant differences in mean Rf among the crops, based on the ANOVA $(P<0.001$; Table 3). Again, winter wheat plots sustained the greatest overall increase in $P$. neglectus populations, with a mean $\mathrm{Rf}$ of 11.8 . There was no evidence from Fisher's LSD test that mean Rf of winter wheat was significantly different from that of canola, which exhibited mean Rf of 4.9. Similar to 2008, P. neglectus population densities in plots of pea, barley, and camelina remained relatively unchanged from their spring levels. In 2009, the only crop for which an overall reduction in nematode populations was observed was in lentil plots, where nematode populations declined to $27 \%$ of their original level. On average, populations of $P$. neglectus in fallow treatment plots declined to $40 \%$ of their original population but the mean Rf of fallow was not significantly different from those of barley and camelina, which exhibited approximately neutral mean $\mathrm{Rf}$ values of 1.0 and 1.1, respectively.

Results obtained from a second ANOVA, comparing mean $P$. neglectus ORf between fall 2008 and spring 2009 under treatment plots, indicated that there were significant differences in mean ORf among the 2008 rotation crops $(P<0.0001$, Table 4$)$. Although the mean winter wheat ORf value was greater than 1 and mean ORf for barley was less than 1, the two means were not significantly different, according to Fisher's protected LSD test. All other treatments in the study had mean ORf values that were significantly less than 1. Estimated mean ORf values for crops with significantly negative effects on $P$. neglectus population density were 0.19 for camelina, 0.09 for canola, 0.08 for pea, and 0.05 for lentil.

Analysis of the AUPC showed that rotations starting with winter wheat generally had higher populations than those starting with the alternative crops (Table 5). The greatest increases occurred when canola and pea followed winter wheat, and the mean AUPC of both of these treatments were found to be significantly different from all others based on Fisher's LSD test $(P<0.05)$. The rotations of winter wheat following barley, lentil, camelina, and pea resulted in the lowest AUPC, and significant differences among these means were not inferred from the LSD test $(P>0.05)$.

For the 2009 study, an ANOVA $F$ test indicated significant differences $(P=0.035)$ in mean winter wheat yield among the previous year's crop treatments (Table 6). Based on the protected Fisher's LSD test, there were no significant differences among the mean winter wheat yields following fallow, pea, lentil, and canola plantings in

Table 4. Pratylenchus neglectus overwinter reproductive factors (ORf) between fall 2008 and spring 2009

\begin{tabular}{|c|c|c|c|c|}
\hline \multirow[b]{2}{*}{2008 Crop } & \multicolumn{2}{|c|}{$\begin{array}{c}\text { Mean population } \\
\text { (nematodes/kg of soil) }\end{array}$} & \multirow[b]{2}{*}{ Mean ORf ${ }^{c}$} & \multirow[b]{2}{*}{ Mean $\log (\text { ORf })^{d}$} \\
\hline & Fall 2008a & Spring $2009^{b}$ & & \\
\hline Winter wheat & 2382 & 3600 & 1.96 & 0.1695 \\
\hline Barley & 474 & 226 & 0.81 & -0.3986 \\
\hline Fallow & 1447 & 304 & 0.47 & -0.6438 \\
\hline Camelina & 594 & 91 & 0.19 & -0.8078 \\
\hline Canola & 2393 & 230 & 0.09 & -1.0389 \\
\hline Pea & 567 & 48 & 0.08 & -1.0560 \\
\hline Lentil & 522 & 32 & 0.05 & -1.1855 \\
\hline $\operatorname{LSD}_{0.05}{ }^{\mathrm{e}}$ & $\ldots$ &.. & & 0.6215 \\
\hline \multicolumn{5}{|c|}{$\begin{array}{l}\text { a Pf } 2008=P \text {. neglectus } \text { population density as determined postharvest in fall } \\
2008 . \\
\text { b Pi } 2009=P \text {. neglectus population density as determined postemergence in } \\
\text { spring } 2009 \text {. } \\
\text { c ORf computed as } \mathrm{Pi} 2009 / \mathrm{Pf} 2008 \text {. }\end{array}$} \\
\hline
\end{tabular}

the previous year, but there was a significant difference in mean 2009 winter wheat yield between fallow and camelina, as well as between fallow and barley and pea and barley. No evidence was provided from the post hoc tests that 2009 mean yields following barley, camelina, canola, and lentil were significantly different. Winter wheat following fallow had the highest 2009 mean yield.

Greenhouse and field barley trials. Barley field cultivar trials. Mean initial P. neglectus population densities for 2008 and 2009 were 1,339 and 711 nematodes/kg of soil, respectively. Across all cultivars tested in 2008, mean Rf was 1.22, and for 2009 it was 0.92. Data from the 2008 and 2009 trials were combined and analyzed as a single data set, based on an $F$-max test for homogeneity of variance. Evidence obtained from an ANOVA $F$ test indicated no significant differences in mean $P$. neglectus $\mathrm{Rf}$ among the cultivars across years $(P=0.92)$. The overall mean Rf across both years' trials was 1.09 , and no evidence was acquired from the statistical tests to suggest the overall mean $\mathrm{Rf}$ to be significantly different from neutral.

Barley greenhouse cultivar trials. Data from the 2008 and 2009 greenhouse resistance screenings were combined and analyzed as a single data set, based on the $F$-max test for homogeneity of variance. Results from the ANOVA $F$ test indicated significant differences in mean final $P$. neglectus $\mathrm{Rf}$ among the cultivars evaluated $(P<0.01$; Table 7). Initial inoculum for the combined experiments averaged 1,000 nematodes/plant. Mean Rf across all entries were less than 1 in both trials, indicating that $P$. neglectus populations declined on average. Mean Rf across both trials was 0.53 . No cultivar sustained a net increase in $P$. neglectus populations during the second trial. Susceptible 'Machete' wheat exhibited a mean Rf of 0.91 over both trials, while resistant 'Excalibur' wheat had a mean Rf of 0.39 . However, despite this observed difference in means, the difference was not significant $(P>0.05)$. Analysis of the combined data set showed that only 'Stellar ND' and 'Tradition' exhibited a mean Rf greater than 1; however, there was no evidence that the mean Rf of either 'Stellar ND' and 'Tradition' was significantly different from neutral $(\mathrm{Rf}=1)$, or from that of five of the other cultivars evaluated (Drummond, Haxby, Boulder, Merit, and Legacy). Furthermore, results of the post hoc tests provided evidence that the mean Rf of 15 of the barley cultivars, along with that of resistant wheat cultivar Excalibur, were significantly different from 1.

\section{Discussion}

Results of the 2006-2007 statewide survey make up the first assessment of root lesion nematodes ( $P$. neglectus and $P$. thornei) affecting wheat in the state of Montana. The primary finding from the survey was that, although $P$. neglectus was found to be widely distributed throughout the state, $P$. thornei was not detected. The current known distribution of $P$. thorne $i$ in North America now extends from the state

Table 5. Area under the population curve (AUPC) for 2-year rotations ${ }^{\mathrm{a}}$

\begin{tabular}{llcc}
\hline Crop year 1 & Crop year 2 & Mean AUPC & Mean $\log (\mathbf{A U P C})^{\mathbf{b}}$ \\
\hline Winter wheat & Canola & 15,509 & 4.17 \\
Winter wheat & Pea & 8,961 & 3.93 \\
Winter wheat & Fallow & 6,451 & 3.79 \\
Winter wheat & Camelina & 6,880 & 3.74 \\
Winter wheat & Barley & 5,959 & 3.73 \\
Canola & Winter wheat & 3,630 & 3.53 \\
Winter wheat & Lentil & 4,522 & 3.51 \\
Fallow & Winter wheat & 2,941 & 3.44 \\
Barley & Winter wheat & 2,654 & 3.39 \\
Lentil & Winter wheat & 2,209 & 3.27 \\
Camelina & Winter wheat & 1,541 & 3.16 \\
Pea & Winter wheat & 1,332 & 3.10 \\
LSD $_{0.05}{ }^{\mathrm{c}}$ & $\ldots$ & $\ldots$ & 0.32 \\
\hline
\end{tabular}

a AUPC calculated across four observations taken 15 May and 23 October 2008, and 27 May and 3 September 2009. Analysis of variance was performed using log transformation of AUPC to normalize variances.

b Significant differences in mean AUPC among rotation treatments ( $F$ test, $P<0.0001)$.

${ }^{c}$ Least significant difference (LSD, $\alpha=0.05$ ) value for mean $\log$ (AUPC). 
of California, north to Washington state, east to Colorado, and farther northeast into southern Ontario (Yu 1997). The absence of $P$. thorne $i$ is likely due to having not been introduced into Montana at this time. The reproductive capabilities of neither $P$. neglectus nor $P$. thornei are greatly inhibited by soil type or moisture, because both species have been found in clay loams, silt loams, irrigated sandy loams, and dryland wheat fields averaging as little as $25 \mathrm{~cm}$ of annual precipitation (Smiley 2015). Although conditions in Montana are cooler than those of the Pacific Northwest that favor $P$. thornei over $P$. neglectus, most other factors (including, but not limited to, soil type and moisture levels) are conducive to the presence of this species. The lack of $P$. thorne $i$ has important control implications, because host resistances to the two species are independently inherited traits (Farsi et al. 1995) and their respective host ranges vary. This finding greatly simplifies the management challenge facing wheat production in Montana.

$P$. neglectus was found primarily within the central winter-wheatgrowing regions of Montana. Finding greater population densities of $P$. neglectus in fields following a winter wheat crop than a spring wheat crop in 2006 was unexpected, because there were fewer reports of injury in winter wheat than spring wheat at the time (Mojtahedi and Santo 1992). Greater nematode population densities in winter wheat are likely due to a longer growing season and the fact that this crop is less conducive to rotations. Winter wheat crop cycles in Montana typically last a period of 9 to 10 months, compared with 4 to 5 months for spring wheat. In the northeast corner of Montana where low or no populations of root lesion nematodes were detected, spring wheat is typically grown in rotation with safflower, flax, and field pea, crops that are generally reported to be poor hosts of $P$. neglectus (Smiley et al. 2005c). Furthermore, studies have shown the minimum root temperature for development of populations of P. neglectus is $7^{\circ} \mathrm{C}$ (Umesh and Ferris 1992), which may suggest that this nematode has the ability to survive and reproduce within host roots even during the course of inclement Montana winters. Taken together, these observations, along with our findings, indicate that winter wheat host plants provide a more favorable opportunity for amplification of $P$. neglectus populations than spring wheat hosts. This tendency has been supported by a more recent study conducted in the region, which showed that annually cropped winter wheat resulted in significantly greater population densities of $P$. neglectus than annually cropped spring wheat (Smiley et al. 2013).

It is established that nematode damage to crops correlates strongly with spring population numbers, which indicate the inoculum density that will be imposed on the developing plant (Smiley et al. 2004a, 2005c; Vanstone et al. 1998). Studies in Oregon have shown negative correlations between grain yield and spring population densities of $P$. neglectus for spring wheat. For these studies, yield losses of $36 \%$ were reported (Smiley et al. 2005b). Relationships between spring nematode population densities and yield losses have been confirmed for both spring and winter wheat in studies conducted in Montana. Based on these correlations and the 2006-2007 survey data, estimated losses due to root lesion nematodes in 2006 would have been 13 and $4 \%$ for winter wheat and spring wheat, respectively; estimated losses due to root lesion nematodes would have been 15 and $7 \%$ for winter and spring wheat fields, respectively, in 2007. This places $P$. neglectus firmly among the most economically damaging pests

Table 6. Winter wheat yields in 2009 following alternative crops

\begin{tabular}{lc}
\hline 2008 Crop & Yield 2009 (kg/ha) \\
\hline Fallow & 1,625 \\
Pea & 1,506 \\
Lentil & 1,386 \\
Canola & 1,249 \\
Camelina & 1,180 \\
Barley & 1,111 \\
LSD $_{0.05}{ }^{\text {b }}$ & 391 \\
\hline
\end{tabular}

a Significant differences in mean 2009 winter wheat yield among previous crops $(P=0.035)$.

${ }^{\mathrm{b}}$ Least significant difference (LSD, $\alpha=0.05$ ) value for mean 2009 winter wheat yields. for wheat in Montana. County data from the 2006 and 2007 surveys of Pratylenchus populations are strongly correlated. This emphasizes that samples sizes were adequate for determining the distribution of nematodes throughout the state. Generally, cropping systems are fairly homogeneous within counties and reflect not only grower behavior but also common environmental conditions.

Stunt nematode populations were consistent during both years. These results are similar to those of another survey of plant-parasitic nematodes which concluded that factors such as tillage, crop type, and watering had no effect on stunt nematode populations (Strausbaugh et al. 2004). For fields not containing root lesion nematodes, the high incidence of Tylenchorhynchus nematodes among soil samples acted as a positive control, indicating that soil samples were properly handled and the nematode extraction method was effective. The substantial population densities and wide distribution of stunt nematode suggest that these nematodes may be an additional cause for concern for Montana's wheat producers. Occurrence of stunt nematode was extensive but its importance is not well understood. Given its prevalence, its interaction and pathogenicity with wheat as a pest should be investigated further.

The 2006-2007 survey established that the predominant species of root lesion nematode, $P$. neglectus, is present in the state of Montana and is of concern to growers. Due to a lack of resistant wheat lines, rotations to nonhost crops will become essential components in grower management practices. The 2008-2009 rotation study examined several viable alternative crops for their ability to control root lesion nematodes. The absence of $P$. thorne $i$ simplified this process. The resulting spring to fall population dynamics followed one of three patterns among the rotational crops tested. For wheat and canola, $P$. neglectus population densities significantly increased, indicating that these crops act as good hosts for the parasite, allowing it to not only persist but also reproduce. For fallow, pea, camelina, and barley, population densities of $P$. neglectus did not significantly change. For these crops, the established populations were able to sustain their numbers over the 3 months separating the spring and fall soil assessments. The only crop tested that demonstrated a consistently negative effect on $P$. neglectus population density was lentil. This effect was primarily seen in the second year, when initial populations of the pest were high.

Table 7. Barley greenhouse cultivar trials ${ }^{\mathrm{a}}$

\begin{tabular}{lcc}
\hline Cultivar $^{\mathbf{b}}$ & Mean Pf (nematodes/kg of soil) & Mean $\mathbf{l o g} \mathbf{P f}^{\mathbf{c}}$ \\
\hline Stellar ND & 1,184 & 2.90 \\
Haxby & 924 & 2.76 \\
Machete (S) & 910 & 2.75 \\
Drummond & 970 & 2.73 \\
Tradition & 1,014 & 2.73 \\
Boulder & 742 & 2.63 \\
Merit & 553 & 2.57 \\
Legacy & 470 & 2.57 \\
Excalibur (R) & 392 & 2.50 \\
Conrad & 431 & 2.50 \\
Eslick & 495 & 2.49 \\
MT960225 & 402 & 2.47 \\
Craft & 406 & 2.44 \\
Hockett & 363 & 2.42 \\
Metcalfe & 481 & 2.37 \\
MTLB32 & 244 & 2.27 \\
MT010158 & 236 & 2.24 \\
WPB Xena & 221 & 2.21 \\
Geraldine & 215 & 2.17 \\
Baronesse & 211 & 2.11 \\
Harrington & 247 & 2.10 \\
LSD ${ }_{0.05}{ }^{\text {d }}$ & $\ldots$ & 0.39 \\
\hline
\end{tabular}

${ }^{a}$ Cultivars are ranked by $\log \mathrm{Pf}(\mathrm{Pf}=$ final Pratylenchus neglectus population density as determined 12 weeks after inoculation). Each experimental pot was inoculated with 1000 P. neglectus adults.

${ }^{\mathrm{b}}$ Resistant (R) and susceptible (S) control lines are indicated.

${ }^{\mathrm{c}}$ Significant differences in mean Pf among cultivars $(F$ test, $P<0.001)$.

${ }^{\mathrm{d}}$ Least significant difference (LSD, $\left.\alpha=0.05\right)$ value for mean $\log (\mathrm{Pf})$. 
Initial assessments of population data were disappointing because fallow, pea, and barley have all been reported as good control options by previous research conducted in Australia and the Pacific Northwest (Smiley et al. 2004a; Taylor et al. 2000). It was suspected that these dynamics were misleading because nematodes present in soil samples from these rotational crops appeared listless, were not producing eggs, and had clear intestinal regions, indicating a lack of recent feeding (data not presented). For fallow treatments, the observed increase in $P$. neglectus population density between spring and fall 2008 was thought to have been a chance occurrence stemming from the low initial levels of inoculum, and was unrelated to growth of volunteer plants and weeds, which were controlled for the growing season in these plots. These observations were prescient because $P$. neglectus populations declined, on average, over the winter of 2008-2009 following fallow, pea, and barley. Unfortunately, the experimental design did not include observations in spring 2010 to allow for a repeated observation of this dynamic. However, a recent report from Oregon has demonstrated that winter survival plays an important role in the population dynamics of $P$. neglectus (Smiley et al. 2013). Montana has a particularly short crop season that may make these effects even more pronounced, making it more important that crop and treatment evaluations for this pest involve overwinter survival assessments. When reevaluated using overwintering data, fallow, pea, camelina, and canola displayed the most substantial declines in nematode populations during the winter period.

Data from this study agree with others in that winter wheat and canola appear to be good hosts for P. neglectus (Fatemy et al. 2006; Taylor et al. 2000). Plots of canola following winter wheat exhibited the highest mean $P$. neglectus population density. However, overwintering populations following canola dramatically declined, possibly due to biofumigation. The biofumigant concept is supported by previous studies (Kirkegaard and Sarwar 1999; Potter et al. 1998) that showed breakdown products of canola glucosinolates to be lethal to root lesion nematodes. The canola data also suggest that, despite canola's perceived strong hosting ability, it may, in fact, have an overall neutral effect on root lesion nematodes, because populations of the pathogen dropped back to nondamaging levels by the time the subsequent wheat crop was planted. Unlike the situation observed with canola, pea, and camelina, $P$. neglectus population density following winter wheat continued to increase from fall to spring despite fields being fallowed at that time. Because volunteer and weed control did not occur in these plots until spring 2009, the increase in P. neglectus population density may be at least partially attributable to growth of volunteer and weed host plants. However, this observation may also suggest that dead wheat root tissues continue to provide food and refuge for populations of $P$. neglectus even after harvest in no-till systems.

Barley cultivars resistant to root lesion nematodes would be beneficial to regional growers, because barley is already a wellestablished, profitable rotation on Montana grain farms. Resistance screenings were conducted in both the field and the greenhouse. Data from the greenhouse cultivar resistance screening indicated significant differences in mean final $P$. neglectus population density among entries. 'Harrington' barley showed considerable potential in terms of its resistance; $P$. neglectus populations decreased to an estimated one-quarter of their original populations in pots planted with this cultivar. Conversely, 'Stellar ND' supported a modest increase in nematode populations. The differences observed in mean Rf among these cultivars may warrant replacing 'Haxby', one of the least resistant barley cultivars tested in the greenhouse trial, with a more resistant variety such as 'Harrington' in future rotational studies. Although past research has been conflicted on the impact of barley on root lesion nematodes (Gair et al. 1969; Smiley et al. 2008), more recent studies have identified moderately resistant phenotypes in wild and cultivated barley accessions, and five quantitative trait loci associated with resistance to $P$. neglectus have been mapped in the barley genome (Kiel et al. 2009; Sharma et al. 2011). Further screening of adapted barley germplasm could prove useful for Montana small grain producers seeking to actively exploit readily available resistance in their wheat-barley rotations.

Results from the field resistance screening suggest that the controlled environment of the greenhouse is more appropriate for detecting cultivar separation with respect to nematode resistance. The lack of separation in mean Rf for cultivars in the field trials was not surprising, because such studies have considerably more uncontrolled and confounding factors than greenhouse trials. These include but are not limited to variability in initial nematode populations, differences in soil moisture levels (Govaerts et al. 2007; López-Fando and Bello 1995), cultural factors (Lenz and Eisenbeis 2000; Thomas 1978), and sampling error.

In summary, the 2006-2007 survey showed significant populations of $P$. neglectus and an absence of $P$. thornei within Montana. Populations of $P$. neglectus were primarily found in soils planted with winter wheat, likely due to its longer duration of growth as well as spring wheat being more amenable to rotations. The subsequent rotational study showed that both winter wheat and canola were good hosts of $P$. neglectus whereas pea, lentil, camelina, and barley were not. Differences among crops were more apparent when spring-tospring rather than spring-to-fall population comparisons were used. The 1 year of spring-to-spring comparisons available indicated that canola plots had substantial postharvest declines, which may be attributable to the decomposition of glucosinolates into compounds toxic to root lesion nematodes. More recently, a Pacific Northwest study found Pratylenchus sp.- and cultivar-specific effects on root lesion nematode populations for pea, chickpea, lentil, and Brassica spp., whereas safflower, sunflower, and flax were all found to be minor or poor hosts of both P. neglectus and P. thornei (Smiley et al. 2014). However, the economic potential of safflower, sunflower, and flax may be lacking and growers may find little benefit in utilizing these crops in rotation with wheat. Greenhouse resistance screenings of barley cultivars demonstrated that useful variation in resistance to $P$. neglectus exists among commercial cultivars that could be exploited in the future. Addressing the yield losses caused by $P$. neglectus is a continuing critical challenge for Montana's wheat production, one that will hopefully be addressed in the future through the rotations to nonhost crops and the development of resistant wheat cultivars.

\section{Acknowledgments}

These projects were funded by the Montana Wheat and Barley Committee Project 4W5153, the United States Department of Agriculture National Institute of Food and Agriculture, Hatch Project number 1002597, and through private donations. We thank D. Wichman (Montana State University) and R. Smiley (Oregon State University) for their ongoing support

\section{Literature Cited}

Appel, J. A., DeWolf, E., Bockus, W. W., and Todd, T. 2012. Kansas Cooperative Plant Disease Survey Report: Preliminary 2012 Kansas Wheat Disease Loss Estimates. Online publication. Kansas Department of Agriculture. https:// agriculture.ks.gov/docs/default-source/pp-disease-reports-2012/2012-ks-wheatdisease-loss-estimates.pdf?sfvrsn=3

Armstrong, J. S., Peairs, F. B., Pilcher, S. D., and Russell, C. C. 1993. The effect of planting time, insecticides, and liquid fertilizer on the Russian wheat aphid (Homoptera: Aphididae) and the lesion nematode (Pratylenchus thornei) on winter wheat. J. Kans. Entomol. Soc. 66:69-73.

CARC. 2016. Monthly and annual precipitation totals 1909-present. Online publication. Montana Agricultural Experiment Station, Central Agricultural Research Center (CARC). http://agresearch.montana.edu/carc/weather/CARCprecip1909.pdf

Doyle, A. D., McLeod, R. W., Wong, P. T. W., Hetherington, S. E., and Southwell, R. J. 1987. Evidence for the involvement of the root-lesion nematode Pratylenchus thornei in wheat yield decline in northern New South Wales. Aust. J. Exp. Agric. 27:563-570.

Farsi, M., Vanstone, V. A., Fisher, J. M., and Rathjen, A. J. 1995. Genetic variation in resistance to Pratylenchus neglectus in wheat and triticales. Aust. J. Exp. Agric. 35:597-602.

Fatemy, S., Abootorabi, E., Ebrahimi, N., and Aghabeigi, F. 2006. First report of Pratylenchus neglectus and $P$. thornei infecting canola and weeds in Iran. Plant Dis. 90:1555.

Gair, R., Mathias, P. L., and Harvey, P. N. 1969. Studies of cereal nematode populations and cereal yields under continuous or intensive culture. Ann. Appl. Biol. 63:503-512.

Govaerts, B., Fuentes, M., Mezzalama, M., Nicol, J. M., Deckers, J., Etchevers, J. D., Figueroa-Sandoval, B., and Sayre, K. D. 2007. Infiltration, soil moisture, root rot, and nematode populations after 12 years of different tillage, residue, and crop rotation managements. Soil Tillage Res. 94:209-219.

Handoo, Z. A., and Golden, A. M. 1989. A key and diagnostic compendium to the species of the genus Pratylenchus Filipjev, 1936 (Lesion Nematodes). J. Nematol 21:202-218. 
Hollaway, G. J., Ophel-Keller, K. M., Taylor, S. P., Burns, R. A., and McKay, A. C. 2003. Effect of soil water content, sampling method, and sample storage on the quantification of root lesion nematodes (Pratylenchus spp.) by different methods. Australas. Plant Pathol. 32:73-79.

Hollaway, G. J., Taylor, S. P., Eastwood, R. F., and Hunt, C. H. 2000. Effect of field crops on density of Pratylenchus neglectus and $P$. thornei in southeastern Australia: Part 2. P. thornei. J. Nematol. 32:600-608.

Johnson, W. A., Johnston, R. H., and Dyer, A. T. 2007. Root lesion nematode (Pratylenchus neglectus) found in wheat fields in Montana. (Abstr.) Phytopathology 97:S53.

Jones, J. T., Haegeman, A., Danchin, E. G. J., Gaur, H. S., Helder, J., Jones, M. G. K., Kikuchi, T., Manzanilla-Lòpez, R., Palomares-Rius, J. E., Wesemael, W. M. L., and Perry, R. N. 2013. Top ten plant-parasitic nematodes in molecular plant pathology. Mol. Plant Pathol. 14:946-961.

Keil, T., Laubach, E., Sharma, S., and Jung, C. 2009. Screening for resistance in the primary and secondary gene pool of barley against the root-lesion nematode Pratylenchus neglectus. Plant Breed. 128:436-442.

Kimpinski, J., Johnston, H. W., and Martin, R. A. 1987. Influence of aldicarb on root lesion nematodes, leaf diseases, and root rot in wheat and barley. Plant Pathol. 36:333-338.

Kirkegaard, J. A., and Sarwar, M. 1999. Glucosinolate profiles of Australian canola (Brassica napus annua L.) and Indian mustard (Brassica juncea L.) cultivars: Implications for biofumigation. Aust. J. Agric. Res. 50:315-324.

Kratochvil, R. J., Sardanelli, S., Everts, K., and Gallagher, E. 2004. Evaluation of crop rotation and other cultural practices for management of root-knot and lesion nematodes. Agron. J. 96:1419-1428.

Kuehl, R. O. 2000. Design of Experiments: Statistical Principles of Research Design and Analysis, 2nd ed. Duxbury Press, Pacific Grove, CA.

Lenz, R., and Eisenbeis, G. 2000. Short-term effects of different tillage in a sustainable farming system on nematode community structure. Biol. Fertil. Soils 31:237-244.

López-Fando, C., and Bello, A. 1995. Variability in soil nematode populations due to tillage and crop rotation in semi-arid Mediterranean agrosystems. Soil Tillage Res. 36:59-72

Mai, P. L., and Mullin, K. F. 1960. Page 150 in: Plant-Parasitic Nematodes: A Pictorial Key to Genera. Ithaca Press and Associates, Ithaca, London.

May, D. B. 2015. Breeding for root lesion nematode resistance in Montana winter wheat. MS thesis, Montana State University, Bozeman.

McVay, K., Burrows, M., Jones, C., Wanner, K., and Menalled, F. 2009. Montana barley production guide. Online publication. Montana State University Extension. http://store.msuextension.org/publications/AgandNaturalResources/ EB0186.pdf

McVay, K., Burrows, M., Menalled, F., Jones, C., Wanner, K., and O’Neill, R. 2013. Montana Cool-Season Pulse Production Guide. Online publication. Montana State University Extension. http://store.msuextension.org/publications/ AgandNaturalResources/EB0210.pdf

McVay, K., Burrows, M., Menalled, F., and Wanner, K. 2010. Montana Wheat Production Guide. Online publication. Montana State University Extension. http://store.msuextension.org/publications/AgandNaturalResources/EB0197. pdf

McVay, K. A., and Lamb, P. F. 2008. Camelina Production in Montana. Online publication. Montana State University Extension. http://store.msuextension. org/publications/AgandNaturalResources/MT200701AG.pdf

Mojtahedi, H., and Santo, G. 1992. Pratylenchus neglectus on dryland wheat in Washington. Plant Dis. 76:323.

National Agricultural Statistics Service (NASS). 2004. Pages 1095-7278 in: Montana 2004 Agricultural Statistics, 2002-2003 County Estimates. NASS., Government Printing Office, Washington, D.C.

Nicol, J. M., Davies, K. A., Hancock, T. W., and Fisher, J. M. 1999. Yield loss caused by Pratylenchus thornei on wheat in South Australia. J. Nematol. 31: 367-376.

Nicol, J. M., and Ortiz-Monasterio, I. 2004. Effects of the root-lesion nematode, Pratylenchus thornei, on wheat yields in Mexico. Nematology 6:485-493.

Nicol, J. M., Rivoal, R., Taylor, S., and Zaharieva, M. 2003. Global importance of cyst (Heterodera spp.) and lesion nematodes (Pratylenchus spp.) on cereals: Distribution, yield loss, use of host resistance and integration of molecular tools. Nematol. Monogr. Perspect. 2:1-19.

Nicol, J. M., Rivoal, R., Trethowan, R. M., van Ginkel, M., Mergoum, M., and Singh, R. P. 2001. CIMMYT's approach to identify and use resistance to nematodes and soil-borne fungi, in developing superior wheat germplasm. Pages 381-389 in: Wheat in a Global Environment. Z. Bedö and L. Láng, eds. Kluwer Academic Publishers, Dordrecht, The Netherlands.

Nombela, G., and Romero, M. D. 1999. Host response to Pratylenchus thornei of a wheat line the $C r e 2$ gene for resistance to Heterodera avenae. Nematology $1: 381-388$.

Potter, M. J., Davies, K., and Rathjen, A. J. 1998. Suppressive impact of glucosinolates in Brassica vegetative tissues on root lesion nematode Pratylenchus neglectus. J. Chem. Ecol. 24:67-80.

Riga, E., Porter, L. D., Motjahedi, H., and Erickson, D. 2008. Pratylenchus neglectus, P. thornei, and Paratylenchus hamatus nematodes causing yield reduction to dryland peas and lentils in Idaho. Plant Dis. 92:979.

Sharma, S., Sharma, S., Kopisch-Obuch, F. J., Kiel, T., Laubach, E., Stein, N., Graner, A., and Jung, C. 2011. QTL analysis of root-lesion nematode resistance in barley: 1. Pratylenchus neglectus. Theor. Appl. Genet. 122 $1321-1330$

Sheedy, J. G., Smiley, R. W., Easley, S. A., and Thompson, A. L. 2008 Resistance of Pacific Northwest spring wheat and barley cultivars to rootlesion nematode, 2007; Pratylenchus thornei. Plant Disease Management Reports 2:N007.

Sheedy, J. G., Thompson, J. P., and Kelly, A. 2012. Diploid and tetraploid progenitors of wheat are valuable sources of resistance to the root lesion nematode Pratylenchus thornei. Euphytica 186:377-391.

Smiley, R. W. 2015. Root-lesion nematodes: Biology and management in Pacific Northwest wheat cropping systems. Pacific Northwest Extension Publishing, Corvallis, OR

Smiley, R. W., and Machado, S. 2009. Pratylenchus neglectus reduces yield of winter wheat in dryland cropping systems. Plant Dis. 93:263-271.

Smiley, R. W., Machado, S., Gourlie, J. A., Pritchett, L. C., Yan, G. P., and Jacobsen, E. E. 2013. Effects of crop rotations and tillage on Pratylenchus spp. in the semiarid Pacific Northwest United States. Plant Dis. 97:537-546.

Smiley, R. W., Merrifield, K., Patterson, L.-M., Whittaker, R. G., Gourlie, J. A., and Easley, S. A. 2004a. Nematodes in dryland field crops in the semiarid Pacific Northwest United States. J. Nematol. 36:54-68.

Smiley, R. W., and Nicol, J. M. 2009. Nematodes which challenge global wheat production. Pages 171-187 in: Wheat Science and Trade. B. F. Carver, ed. Wiley-Blackwell, Ames, IA.

Smiley, R. W., Sheedy, J. G., and Easley, S. A. 2005a. Root-Lesion Nematode on Wheat: Yield Loss and Control. Columbia Basin Agricultural Research Center Publication Pendleton, OR.

Smiley, R. W., Sheedy, J. G., and Easley, S. A. 2008. Vertical distribution of Pratylenchus spp. in silt loam soil and Pacific Northwest dryland crops. Plant Dis. 92:1662-1668.

Smiley, R. W., Whittaker, R. G., Gourlie, J. A., and Easley, S. A. 2005b. Pratylenchus thornei associated with reduced wheat yield in Oregon. J. Nematol. 37:45-54.

Smiley, R. W., Whittaker, R. G., Gourlie, J. A., and Easley, S. A. 2005c Suppression of wheat growth and yield by Pratylenchus neglectus in the Pacific Northwest. Plant Dis. 89:958-968.

Smiley, R. W., Whittaker, R. G., Gourlie, J. A., Easley, S. A., Rhinhart, K., Jacobsen, E., Burnett, A., Jackson, J., Kellogg, D., Skirvin, J., and Zeckman, T. 2004b. Lesion nematodes reduce yield in annual spring wheat. Oregon Agr. Expt. Stn. Spec. Rpt. 1054:120-127.

Smiley, R. W., Yan, G., and Gourlie, J. A. 2014. Selected Pacific Northwest crops as hosts of Pratylenchus neglectus and Pratylenchus thornei. Plant Dis. 98 $1341-1348$

Strausbaugh, C. A., Bradley, C. A., Koehn, A. C., and Forster, R. L. 2004. Survey of root diseases of wheat and barley in southeastern Idaho. Can. J. Plant Pathol. 26:167-176.

Taylor, S. P., and Evans, M. L. 1998. Vertical and horizontal distribution of and sampling for root lesion nematodes (Pratylenchus neglectus and P. thornei) in South Australia. Australas. Plant Pathol. 27:90-96.

Taylor, S. P., Hollaway, G. J., and Hunt, C. H. 2000. Effect of field crops on population densities of Pratylenchus neglectus and P. thornei in Southeastern Australia; Part 1: P. neglectus. J. Nematol. 32:591-599.

Taylor, S. P., Vanstone, V. A., Ware, A. H., McKay, A. C., Szot, D., and Russ, M. H. 1999. Measuring yield loss in cereals caused by root lesion nematodes (Pratylenchus neglectus and $P$. thornei) with and without nematicide. Aust. J. Agric. Res. 50:617-622.

Thomas, S. H. 1978. Population densities of nematodes under seven tillage regimes. J. Nematol. 10:24-27.

Thompson, J. P., Brennan, P. S., Clewett, T. G., Sheedy, J. G., and Seymour, N. P. 1999. Progress in breeding wheat for tolerance and resistance to root-lesion nematode (Pratylenchus thornei). Australas. Plant Pathol. 28:45-52.

Thompson, J. P., Clewett, T. G., Sheedy, J. G., Reen, R. A., O'Reilly, M. M., and Bell, K. L. 2008a. Occurrence of root-lesion nematodes (Pratylenchus thornei and P. neglectus) and stunt nematode (Merlinus brevidens) in the northern grain region of Australia. Australas. Plant Pathol. 39:254-264.

Thompson, J. P., and Haak, M. I. 1997. Resistance to root-lesion nematode (Pratylenchus thornei) in Aegilops tauschii Coss., the D-genome donor to wheat. Aust. J. Agric. Res. 48:553-559.

Thompson, J. P., MacKenzie, J., and Amos, R. 1995. Root-lesion nematode (Pratylenchus thornei) limits response of wheat but not barley to stored soil moisture in the Hermitage long-term tillage experiment. Aust. J. Exp. Agric. 35:1049-1055.

Thompson, J. P., Owen, K. J., Stirling, G. R., and Bell, M. J. 2008b. Root-lesion nematodes (Pratylenchus thornei and P. neglectus): A review of recent progress in managing a significant pest of grain crops in northern Australia. Australas. Plant Pathol. 37:235-242.

Toktay, H., McIntyre, C. L., Nicol, J. M., Ozkan, H., and Elekçioğlu, H. İ. 2006. Identification of common root-lesion nematode (Pratylenchus thornei Sher et Allen) loci in bread wheat. Genome 49:1319-1323.

Umesh, K. C., and Ferris, H. 1992. Effects of temperature on Pratylenchus neglectus and on its pathogenicity to barley. J. Nematol. 24:504-511.

Van Gundy, S. D., Perez, J. G., Stolzy, L. H., and Thomason, I. J. 1974. A pest management approach to the control of Pratylenchus thornei on wheat in Mexico. J. Nematol. 6:107-116. 
Vanstone, V. A., Hollaway, G. J., and Stirling, G. R. 2008. Managing nematode pests in the southern and western regions of the Australian cereal industry: Continuing progress in a challenging environment. Australas. Plant Pathol. 37:220-234.

Vanstone, V. A., Rathjen, A. J., Ware, A. H., and Wheeler, R. D. 1998. Relationship between root lesion nematodes (Pratylenchus neglectus and P. thornei) and performance of wheat varieties. Aust. J. Exp. Agric. 38:181-188.

Whitehead, A. G., and Hemming, J. R. 1965. A comparison of some quantitative methods of extracting small vermiform nematodes from soil. Ann. Appl. Biol. 55:25-38.

Williams, K. J., Taylor, S. P., Bogacki, P., Pallotta, M., Bariana, H. S., and Wallwork, H. 2002. Mapping of the root lesion nematode (Pratylenchus neglectus) resistance gene Rlnn1 in wheat. Theor. Appl. Genet. 104:874-879.
Yu, Q. 1997. First report of Pratylenchus thornei from spring wheat in southern Ontario. Can. J. Plant Pathol. 19:289-292.

Yu, Q., Rong, R., Chiba, M., and Potter, J. 2005. Selective nematicidal activity of allyl isothiocyanate. J. Food Agric. Environ. 3:218-221.

Zwart, R. S., Thompson, J. P., and Godwin, I. D. 2004. Genetic analysis of resistance to root-lesion nematode (Pratylenchus thornei) in wheat. Plant Breed. 123:209-212.

Zwart, R. S., Thompson, J. P., and Godwin, I. D. 2005. Identification of quantitative trait loci for resistance to two species of root-lesion nematode (Pratylenchus thornei and P. neglectus) in wheat. Aust. J. Agric. Res. 56: 345-352. 